\title{
Critically Endangered totoaba Totoaba macdonaldi: signs of recovery and potential threats after a population collapse
}

\author{
Fausto Valenzuela-Quiñonez ${ }^{1}$, Francisco Arreguín-Sánchez ${ }^{2}$, \\ Silvia Salas-Márquez ${ }^{3}$, Francisco J. García-De León ${ }^{1}$, John C. Garza ${ }^{4}$, \\ Martha J. Román-Rodríguez ${ }^{5}$, Juan A. De-Anda-Montañez ${ }^{6, *}$ \\ ${ }^{1}$ Catedrático CONACYT. Centro de Investigaciones Biológicas de Noroeste (CIBNOR), La Paz, B.C.S. 23096, Mexico \\ ${ }^{2}$ Centro Interdisciplinario de Ciencias Marinas (CICIMAR), La Paz 23096, B.C.S. Mexico \\ ${ }^{3}$ Centro de Investigación y de Estudios Avanzados del Instituto Politécnico Nacional, Mérida, Yucatán 97310, Mexico \\ ${ }^{4}$ Southwest Fisheries Science Center, National Oceanic and Atmospheric Administration, Santa Cruz, CA 95060, USA \\ ${ }^{5}$ Comisión de Ecología y Desarrollo Sustentable del Estado de Sonora, Jalisco 903 Col. Sonora, San Luis Colorado, \\ Sonora C.P. 83440, Mexico \\ ${ }^{6}$ Centro de Investigaciones Biológicas de Noroeste (CIBNOR), La Paz, B.C.S. 23096, Mexico
}

\begin{abstract}
The lack of long-term monitoring programs makes it difficult to assess signs of population recovery in collapsed marine populations. Fishery-induced changes in the life history of exploited marine fishes, such as truncated size and age structure, local extirpations, reductions in age at maturity, and changes in mortality patterns, have occurred. In the present study, we explored life history aspects of totoaba Totoaba macdonaldi, almost $40 \mathrm{yr}$ after a population collapse, to examine whether totoaba maintained their life history pattern and to identify the potential threats of using fishing gear (hooks, gillnets). The results of the present study indicate that the totoaba size structure was not truncated as expected in overexploited populations; indeed, it was similar to that observed in the past. Totoaba have maintained their known historical distribution range. The spatial size structure and temporal distribution followed the known migration patterns of totoaba. Total and natural mortality were similar. Contrary to recommendations for sustainable fisheries, caught fish contained a large number of juveniles, irrespective of method used. We conclude that the general life history (size structure, distribution, migration, and mortality) has not changed since the fishery collapse. However, the choice of fishing gear could compromise a positive recovery trend of the population. Moreover, poaching is a major ongoing threat to the recovery of totoaba.
\end{abstract}

KEY WORDS: Totoaba $\cdot$ Totoaba macdonaldi $\cdot$ Fishery collapse $\cdot$ Recovery $\cdot$ Gulf of California

\section{INTRODUCTION}

Successful species conservation involves more than preventing extinction; it also includes the recovery of threatened species. Recovery is a process towards a recovered state involving several states: captive, in-

*Corresponding author: jdeanda@cibnor.mx tensive, and light management, and self-sustaining (Redford et al. 2011). Recovery also depends on intrinsic (biological) and extrinsic (anthropogenic) factors (Lotze et al. 2011). Thus, conservation measures should address major threats for the recovery process, such as exploitation, habitat loss, and pollution, to in-

(C) The authors 2015. Open Access under Creative Commons by Attribution Licence. Use, distribution and reproduction are unrestricted. Authors and original publication must be credited. 
crease overall population recovery (Dulvy et al. 2003, Reynolds et al. 2005, Lotze et al. 2011).

There is a growing concern for the health status of marine fish populations, especially when no longterm information is available (Costello et al. 2012). Overexploited and collapsed marine fish populations need a long time to show any signs of recovery; hence, evidence is scarce (Hutchings 2000, Hutchings \& Reynolds 2004). The fishing industry induces changes in the overall life history of marine fish, such as a reduction in the age and size structure, age at maturity, fecundity, and genetic diversity, as well as an increase in the potential for local extinctions (Dulvy et al. 2003, Hoarau et al. 2005, Enberg et al. 2009, Heino et al. 2013). Measuring these changes is useful to detect signs of population recovery (Abbitt \& Scott 2001, Lotze et al. 2011) in the absence of long-term information.

The resilience and recovery of marine fish stocks is negatively influenced through catch selectivity of fishing gear because this can change the age and size structure of the population, leading to negative impacts on the life history of fish (Fisher et al. 2010, Vasilakopoulos et al. 2011, Brunel \& Piet 2013). Fish population reference points based on catch composition of healthy populations elsewhere have been used to avoid the potential threats such as recruitment overfishing and growth overfishing (Froese 2004, Cope \& Punt 2009, Vasilakopoulos et al. 2011, Brunel \& Piet 2013). This information can be used to control the potential threats of different fishing gear to population resilience and conservation management.

Totoaba Totoaba macdonaldi is a large and longlived fish endemic to the Gulf of California (CisnerosMata et al. 1995). At the beginning of the 20th century, it was the first and most important fishery in the gulf. Totoaba distribution ranges from the Colorado River mouth to the Fuerte River mouth along the continental coast of Mexico (Arvizu \& Chávez 1972), and from the Colorado River mouth to Bahía Concepción along the Baja Peninsula. Adult totoaba spawn in the Colorado River delta from late winter to early spring (Flanagan \& Hendrickson 1976, Cisneros-Mata et al. 1995). Juveniles spend 2 to $3 \mathrm{yr}$ in the upper Gulf of California before migrating south in autumn. Both adults and juveniles spend summers at feeding grounds around the islands of Tiburon and Angel de la Guarda, before subsequently moving south in autumn along the Mexican mainland. In winter, totoaba migrate northward again. The adults migrate into the Colorado River delta for spawning, and the juveniles into the island region (Tiburon and Angel de la Guarda) (Cisneros-Mata et al. 1995).
In 1942 , totoaba catches peaked at $>2000 \mathrm{t}$ before subsequently declining to $52 \mathrm{t}$ in 1975 (CisnerosMata et al. 1995). Causes for the totoaba population collapse over $40 \mathrm{yr}$ were overexploitation, habitat degradation, bycatch, and poaching (Flanagan \& Hendrickson 1976, Cisneros-Mata et al. 1995, Lercari \& Chávez 2007). Totoaba fishing was banned in 1975 , totoaba were listed in 1976 as Critically Endangered by the Convention on International Trade (CITES), and in 1979 included in the Endangered Species Act of the USA (Barrera-Guevara 1990). Totoaba are also listed as Critically Endangered in 1996 by the International Union for Conservation of Nature (IUCN) (IUCN 2013).

Despite a ban on totoaba fishing, the main threats to the totoaba population continue to be poaching and bycatch (Valenzuela-Quiñonez et al. 2011, Márquez-Farías \& Rosales-Juárez 2013). A proposal has been submitted to the Mexican government to allow totoaba fishing in sport fishery (ValenzuelaQuiñonez et al. 2014). However, population abundance trends of totoaba are not available because fishing was banned, and the current basic life history information for these fish is also lacking. These data are necessary to confidently assess the totoaba population status (Valenzuela-Quiñonez et al. 2011, 2014). Although, population recovery or stability of totoaba has been suggested, based on historical size structure, mortality rates, and genetic diversity (RosalesJuárez \& Ramírez-González 1987, Román-Rodríguez \& Hammann 1997, Valenzuela-Quiñonez et al. 2014), the current population status is unknown (MárquezFarías \& Rosales-Juárez 2013, Valenzuela-Quiñonez et al. 2014).

In this study, we examined several questions relating to the characteristics of overexploited fisheries, to infer signs of totoaba population stability or potential recovery in the absence of long-term data. (1) What is the size structure of the population? (2) Are totoaba still conserving their known spatial distribution range and migration pattern? (3) What is the spatial size structure? (4) What is the potential impact of hook (sport fishing) and gillnet (poaching) use on the population size structure? We aim to identify if the present-day totoaba population has recovered from its population collapse $40 \mathrm{yr}$ ago, or whether it still shows signs of overexploitation, such as truncated population size structure, contracted species distribution range, changes in migration patterns, and mortality rates. Additionally, we investigated the threats of certain fishing gear use, and its potential impact on the totoaba population. 


\section{MATERIALS AND METHODS}

Fieldwork. Totoaba specimens were collected during 13 field trips between 2010 and 2013 at 7 sites along the Gulf of California: Core Zone $(\mathrm{n}=170)$, Roca Consag ( $\mathrm{n}=65)$, south of San Felipe $(\mathrm{n}=15)$, San Luis Gonzaga $(\mathrm{n}=$ 85), Desemboque $(\mathrm{n}=6)$, Bahía de Lobos $(\mathrm{n}=21)$, and Fuerte River $(\mathrm{n}=1)$ (Fig. 1). Fish were caught using either a 10 -inch $(25.4 \mathrm{~cm})$ gillnet $(120 \mathrm{~m}$ long), or No. 5 and 6 hook lines. The geographic location, body weight (g), length $(\mathrm{mm})$, and sex of the fish were recorded at the time of sampling.

Size structure. The totoaba population size structure was assessed for all individuals, by sex, by location, and by gear. A multimodal distribution model (Haddon 2001) was chosen to estimate the number of the modal size groups for each category:

$P\left\{x_{i} \mid n, p_{1}, p_{2}, \ldots, p_{k}\right\}=n ! \prod_{i=1}^{k} \frac{p_{i}^{\prime x_{i}}}{x_{i} !}$

where $P$ is the probability for the multinomial distribution, $x_{i}$ is the number of times that $i$ events occur in $n$ samples, and $p_{i}^{\prime}$ is the expected probability of each $k$ possible event. Parameter estimates of the model were computed using a log-likelihood expression $(\ln L)$ of Eq. (1):

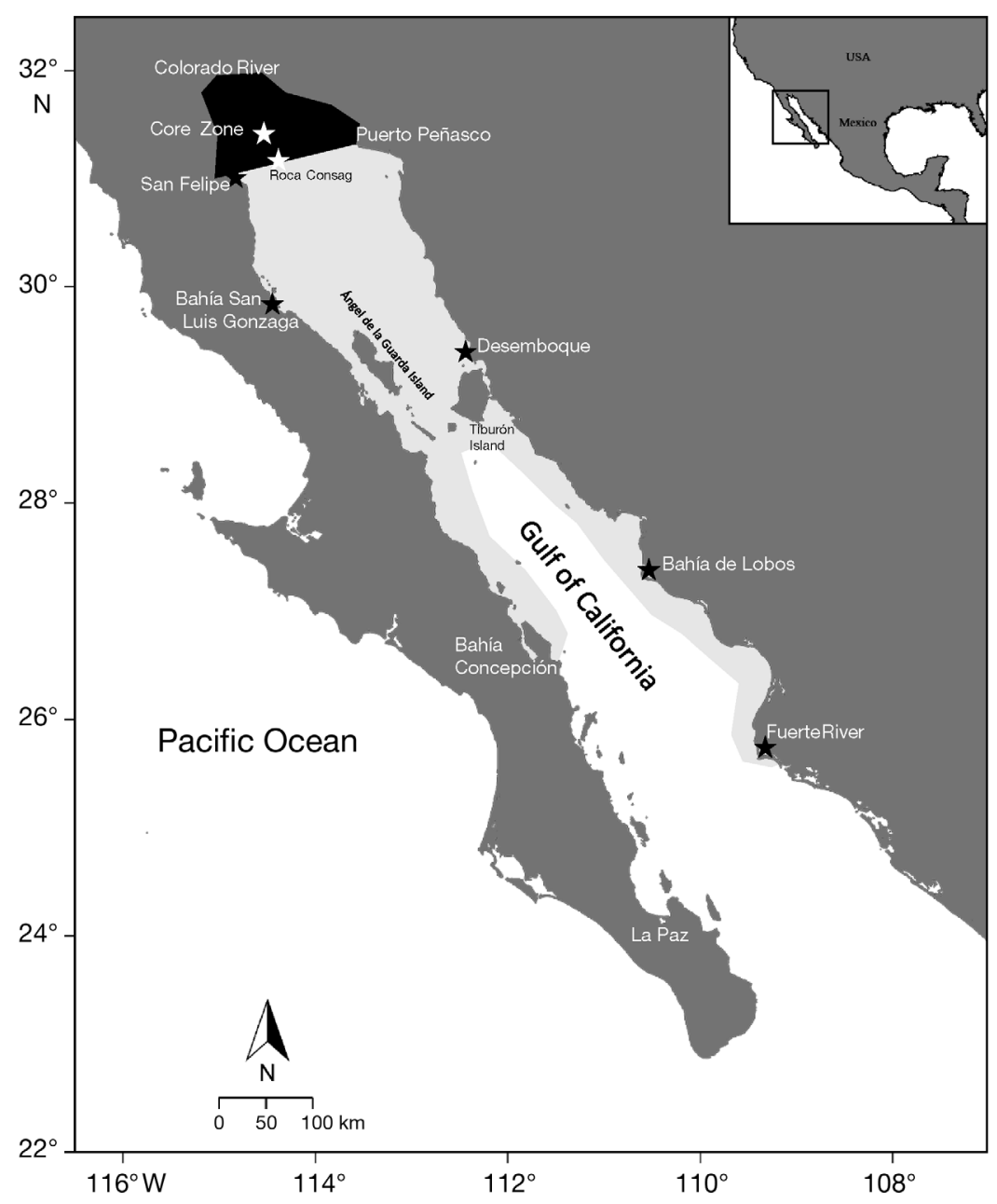

Fig. 1. Gulf of California, Mexico, with the distribution of totoaba Totoaba macdonaldi. The light gray shading indicates the distribution range of totoaba in the Gulf of California. The Biosphere Reserve of the Upper Gulf of California and the Colorado River delta is indicated in black. Stars indicate the collection sites

$$
-\ln L\left\{x_{i} \mid n, p_{1}, p_{2}, \ldots, p_{k}\right\}=\sum_{i=1}^{k}\left[x_{i} \ln \left(p_{i}{ }_{i}\right)\right]
$$

The model assumption is that each modal size group can be described through a normal distribution. Hence, the relative proportions of each length class $\left(P L_{\mathrm{T}}\right)$ can be estimated using the normal distribution assumption:

$$
P L_{\mathrm{T}}=\frac{1}{\sigma_{\mathrm{T}} \sqrt{2 \pi}} \mathrm{e}^{\frac{\left(-L_{\mathrm{T}}-\mu_{\mathrm{T}}\right)^{2}}{2 \sigma_{\mathrm{T}}}}
$$

where $\mu_{\mathrm{T}}$ is the mean and $\sigma_{\mathrm{T}}$ is the standard deviation of the total length $\left(L_{\mathrm{T}}\right)$ of each modal size group. To estimate the parameters and expected frequencies of Eq. (1), observed and estimated frequencies were compared using the negative log-likelihood of multinomial distributions (Haddon 2001, AguirreVillaseñor et al. 2006):

$$
-\ln L\left\{L \mid \mu_{\mathrm{T}}, \sigma_{\mathrm{T}}\right\}=-\sum_{i=1}^{k} L_{i} \ln \left(p_{i}^{\prime}\right)=-\sum_{i=1}^{k} L_{i} \ln \left(\frac{L_{i}^{\prime}}{\sum L_{i}^{\prime}}\right)
$$

where, $k$ are length classes, and $L_{i}^{\prime}$ is the observed frequency of the length class $i$ of the combined normal distribution. The parameters were computed when minimizing the likelihood of Eq. (4) through the means of non-linear estimation, using the Newton algorithm (Neter et al. 1996). 
Seasonal distribution. Totoaba catch data were used to describe changes in the seasonal distribution. The data were plotted using the software package PBSmapping (Schnute et al. 2004) for the R environment (R Development Core Team 2011).

Mortality. The total totoaba mortality $(Z)$ was calculated by first estimating the age of totoaba sampled, using otolith rings following previous validated procedures described in Román-Rodríguez \& Hammann (1997), and then using a linearized catch curve (Sparre \& Vennema 1995). The linearized catch curves plots the logarithm of the catch against age groups (Sparre \& Vennema 1995):

$$
\ln C_{t}=a-Z \times t
$$

where $C_{t}$ is the frequency of the species of age $t$ (yr), $a$ is the intercept, and $Z$ is the slope of the linear regression. Natural mortality $(M)$ was estimated using several methods (Beverton \& Holt 1959, Rikhter \& Efanov 1976, Pauly 1980, Hewitt \& Hoenig 2005, Gislason et al. 2010) (Table 1).

\section{RESULTS}

\section{Size structure}

During the surveys, 360 totoaba specimens were caught. For the entire totoaba population, sizes ranged from 280 to $1860 \mathrm{~mm}$, one modal size group averaged $740 \pm 51 \mathrm{~mm}$ mean \pm standard deviation and the other modal size group averaged $1333 \pm 171 \mathrm{~mm}$ (Fig. 2a). Juvenile sizes ranged from 280 to $1365 \mathrm{~mm}$, comprising one modal size group averaging $755 \pm$ $161 \mathrm{~mm}$ and the other modal size group averaging $1143 \pm 118 \mathrm{~mm}$ (Fig. 2b). Female size ranged from
520 to $1860 \mathrm{~mm}$, made up of 3 modal size groups: 739 $\pm 87,1009 \pm 87$, and $1359 \pm 164 \mathrm{~mm}$ (Fig. 2c, Fig. A1) The sizes of males ranged from 630 to $1651 \mathrm{~mm}$ and comprised 3 similar modal size groups: $702 \pm 47$, $1027 \pm 121$, and $1372 \pm 130 \mathrm{~mm}$ (Fig. 2d, Fig. A1).

The size structures for all sites are summarized in Fig. 3. Large and smaller totoaba were observed in the Core Zone near the Colorado River delta, which consisted of a single modal size group (1375 $\pm 114 \mathrm{~mm}$; Fig. 3a). Roca Consag consisted of 2 modal juvenile size groups (732 \pm 101 and $981 \pm 80$ mm; Fig. 3b). A single modal size group was observed south of San Felipe (1194 \pm 97 mm; Fig. 3c). Similar to Roca Consag, 2 modal juvenile size groups occurred at San Luis Gonzaga (772 \pm 93 and $1066 \pm 115$ mm; Fig. 3d). At Desemboque, 2 modal juvenile size groups were observed (750 \pm 7 and $1120 \pm 40 \mathrm{~mm}$; Fig. 3e), and 2 modal size groups occurred at Bahía de Lobos (601 \pm 123 and $1083 \pm 62$ mm; Fig. 3f).

The choice of gear (hooks or gillnet) used to catch totoaba resulted in different modal size groups. Totoaba caught with hooks fell into 2 modal size groups (746 \pm 91 and $1022 \pm 126$ mm; Fig. 4a). By contrast, gillnet-caught totoaba fell into a single modal size group (1371 140 mm; Fig. 4b).

\section{Seasonal distribution}

The distribution of totoaba along the Gulf of California showed important seasonal variations (Fig. 5). In spring, adults were observed in the Core Zone and south of San Felipe, whereas juveniles were observed at Roca Consag and San Luis Gonzaga (Fig. 5). In autumn, adults were not observed in the Core Zone, but juveniles were present at San Felipe, Roca Con-

Table 1. Methods used to estimate the natural mortality $(M)$ of Totoaba macdonaldi, where $k$ is the growth rate of the von Bertalanffy growth model, $A_{\mathrm{m} 50 \%}$ is the age of first maturity, $A_{\max }$ is the maximum age observed, $L_{\infty}$ is the asymptotic length of the growth model, $T$ is the temperature $\left({ }^{\circ} \mathrm{C}\right)$, and $L$ is the total length $(\mathrm{cm})$. The following parameter values were used: $k=0.13, A_{\mathrm{m} 50 \%}=7 \mathrm{yr}, A_{\max }=30 \mathrm{yr}, L_{\infty}=180 \mathrm{~cm}, T=19^{\circ} \mathrm{C}$, and $L=120 \mathrm{~cm}$ (Cisneros-Mata et al. 1995, De-Anda-Montañez et al. 2013)

\begin{tabular}{ll} 
Method & Equation \\
\hline Beverton \& Holt (1959) & $M \approx 1.5 \times k$ \\
Rikhter \& Efanov (1976) & $M=1.521 /\left(A_{\mathrm{m} 50 \%}{ }^{0.720}\right)-0.155$ \\
Hewitt \& Hoenig (2005) & $M \approx 4.22 / A_{\max }$ \\
Pauly (1980) & $M=0.8 \times \exp \left[-0.0152-0.279^{*} \ln L_{\infty}+0.6543 \times \ln k+0.463 \times \ln A\right]$ \\
Gislason et al. (2010) & $\ln M=0.55-1.61 \ln L+1.44 \ln L_{\infty}+\ln k$
\end{tabular}



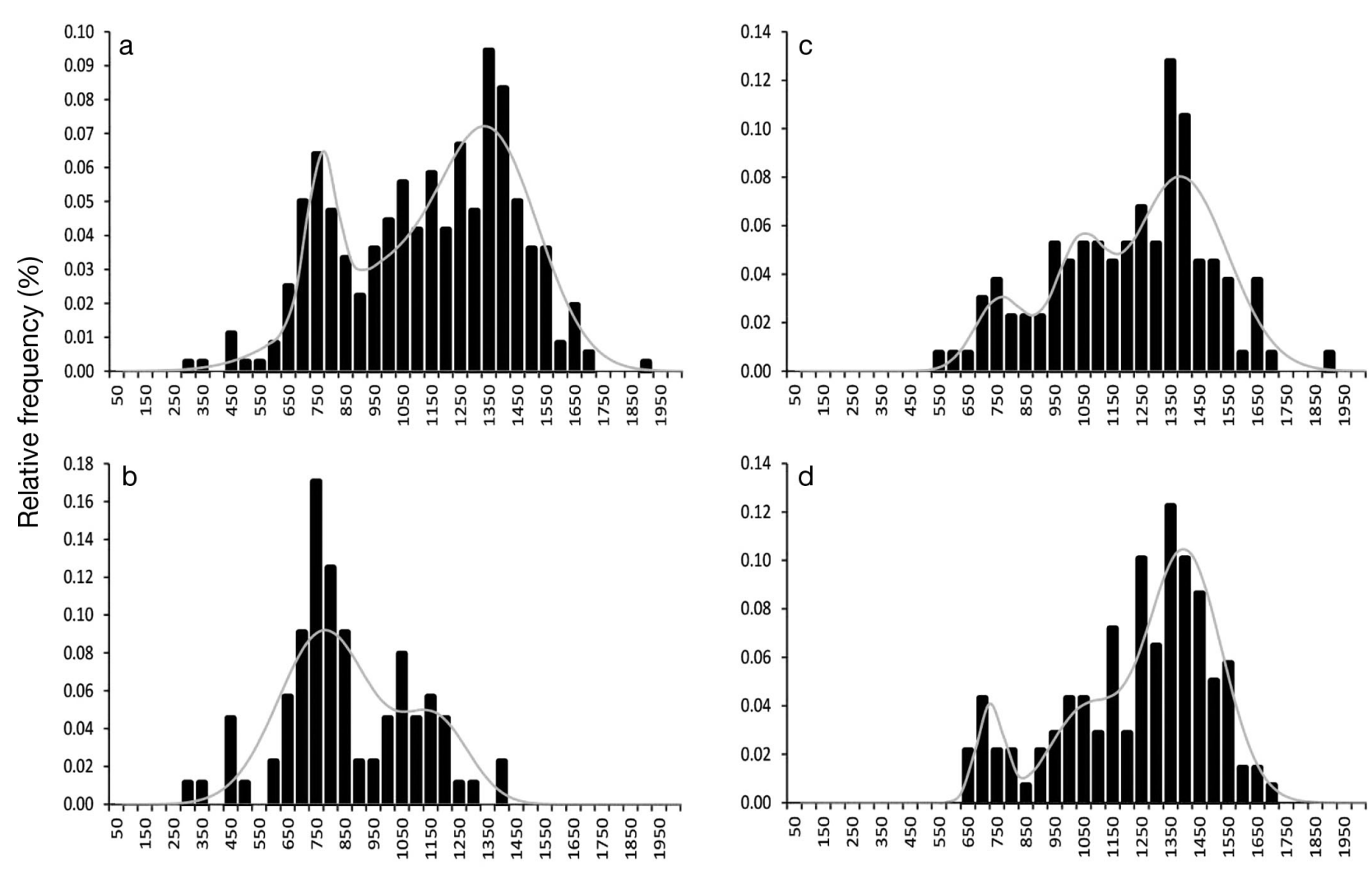

Total length $(\mathrm{mm})$

Fig. 2. Size structure and modal size groups (gray line) of totoaba Totoaba macdonaldi in the Gulf of California for (a) all populations, (b) juveniles, (c) females and (d) males

sag, and San Luis Gonzaga, and showed increased presence southward along the mainland coast to Desemboque (Fig. 5). During winter, adults were observed in the Colorado River delta and the Core Zone, whereas juveniles were observed as far south as Bahía de Lobos and the mouth of the Fuerte River along the mainland coast (Fig. 5).

\section{Mortality}

Total mortality $(Z)$ was computed using a linearized catch curve plot (Fig. 6). The estimate of $Z$ for the totoaba population was $0.22 \mathrm{yr}^{-1}$. Estimates of $M$ for totoaba ranged from 0.14 to $0.22 \mathrm{yr}^{-1}$ dependent on the method used (Table 2).

\section{DISCUSSION}

These results show that totoaba maintained its general life history pattern after the population col- lapse: (1) The size structure was not truncated, as expected for an overexploited species, (2) totoaba maintained a distribution range similar or wider than historical records, (3) the size structure and seasonal distribution fit the known migration pattern, (4) mortality rates were similar to previous estimates, and (5) both hooks and gillnets caught large numbers of juveniles.

Demographic characteristics of fish populations are affected by fishing pressure (Enberg et al. 2009, Eikeset et al. 2013, Heino et al. 2013). The first demographic component affected is the size structure of the population, since captured adults reduce the average length of the population; hence, overexploited populations exhibit truncated size structures (Hilborn \& Walters 1992, Fisher et al. 2010). The size and/or age structure of a fish stock is an important indicator of stock health as this parameter is associated with the life history of the fish (Andersen \& Beyer 2015, Brunel $\&$ Piet 2013). The overall totoaba stock size structure was not truncated, as expected in overexploited populations. These results are similar to reports obtained 

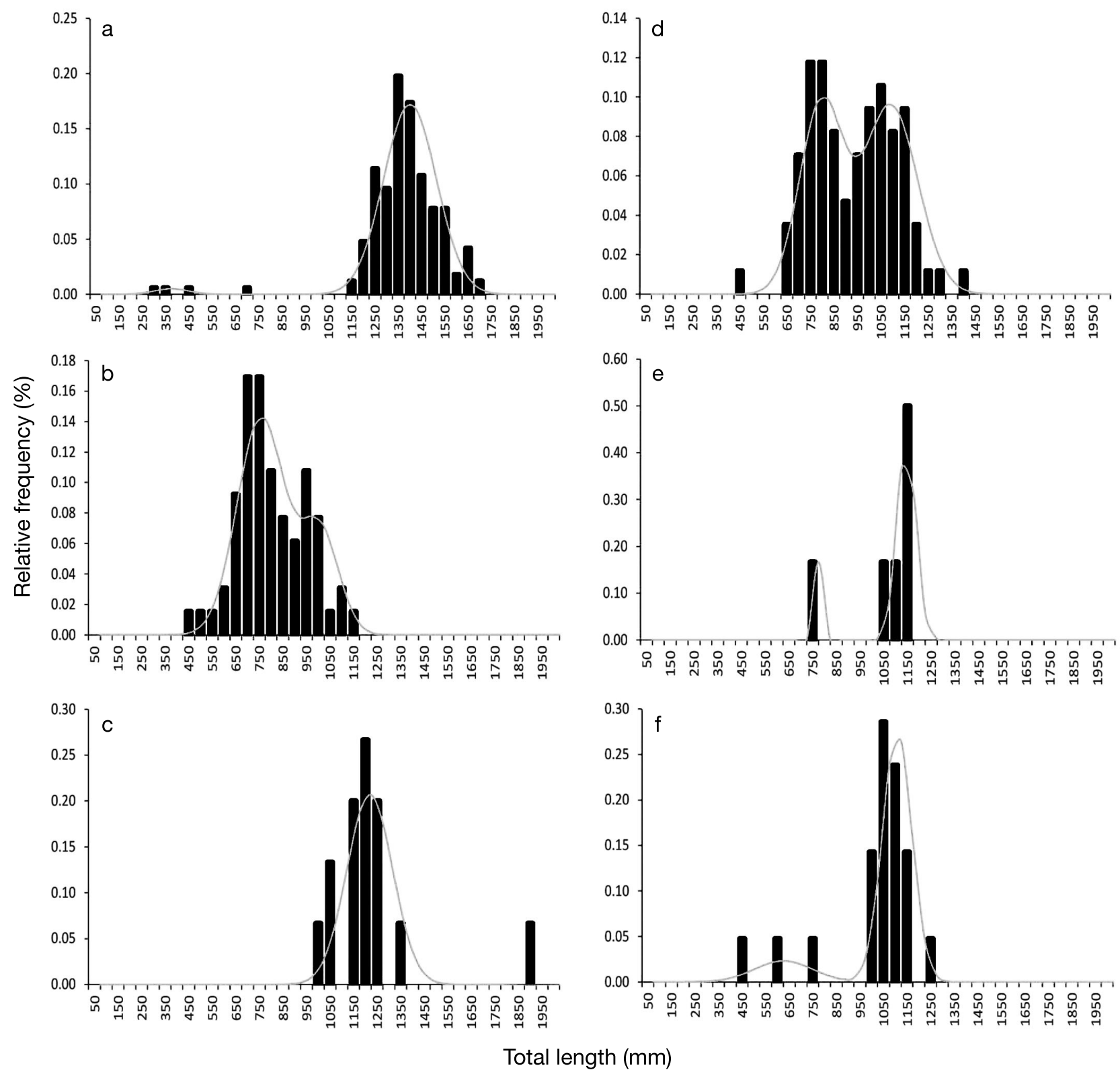

Fig. 3. Size structure and modal size groups (gray line) of totoaba Totoaba macdonaldi in the Gulf of California for (a) Core Zone, (b) Roca Consag, (c) south of San Felipe, (d) San Luis Gonzaga, (e) Desemboque and (f) Bahía de Lobos

in the 1960s, 1980s, and 1990s (Arvizu \& Chávez 1972, Román-Rodríguez \& Hammann 1997, Pedrín-Osuna et al. 2001). Due to the lack of data on totoaba population size structure available from the early days of the totoaba fishery, a meaningful evaluation determining whether the population has recovered to its original (pre-fishing) size structure is not possible. However, the totoaba stock size structure has been stable for several decades.

Distribution is a key component used by the IUCN to assess the threat status of a species (IUCN 2001).
Collapsed marine fish populations potentially show reduced ranges or even local extirpations (Dulvy et al. 2003). Recovered species show larger distribution patterns even exceeding historic ranges compared to non-recovered species (Abbitt \& Scott 2001). The results of the present study indicate that totoaba have maintained their historical range (Arvizu \& Chávez 1972, Flanagan \& Hendrickson 1976, Cisneros-Mata et al. 1995), and their range actually might have increased (J. A. De-Anda-Montañez unpubl. data). CITES indicates that the distribution of totoaba has 


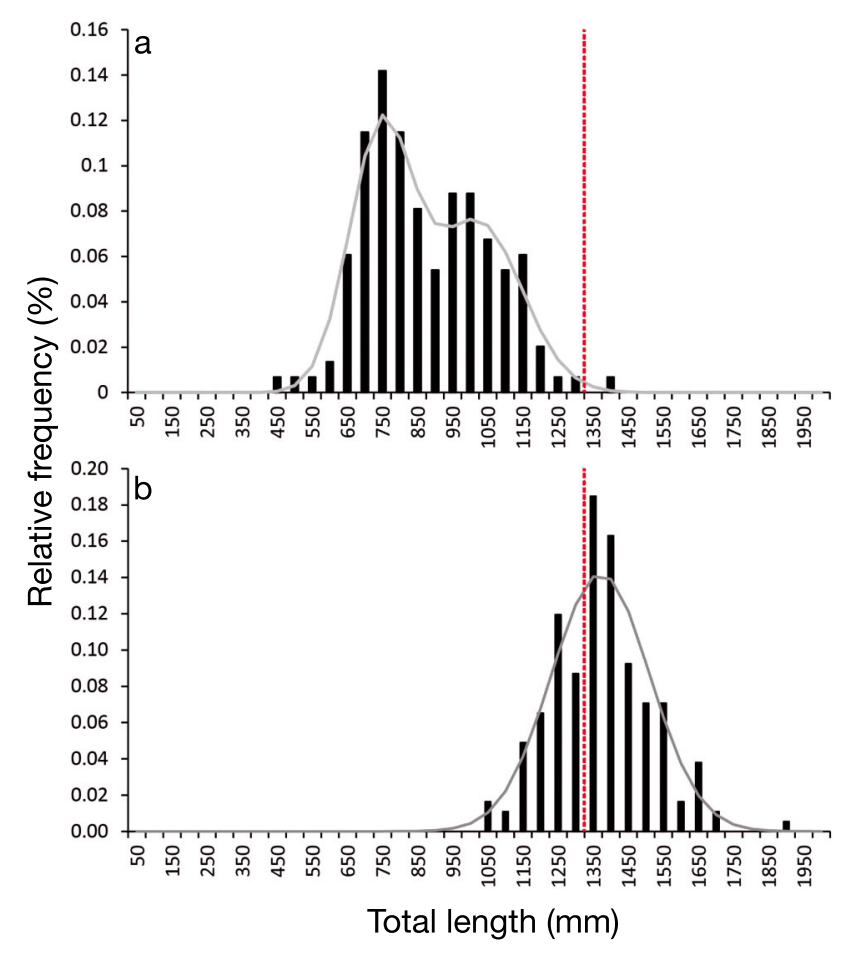

Fig. 4. Size structure and modal size groups of totoaba Totoaba macdonaldi using (gray line) (a) hooks and (b) gillnet. Red dashed line indicates the size of first maturity of totoaba
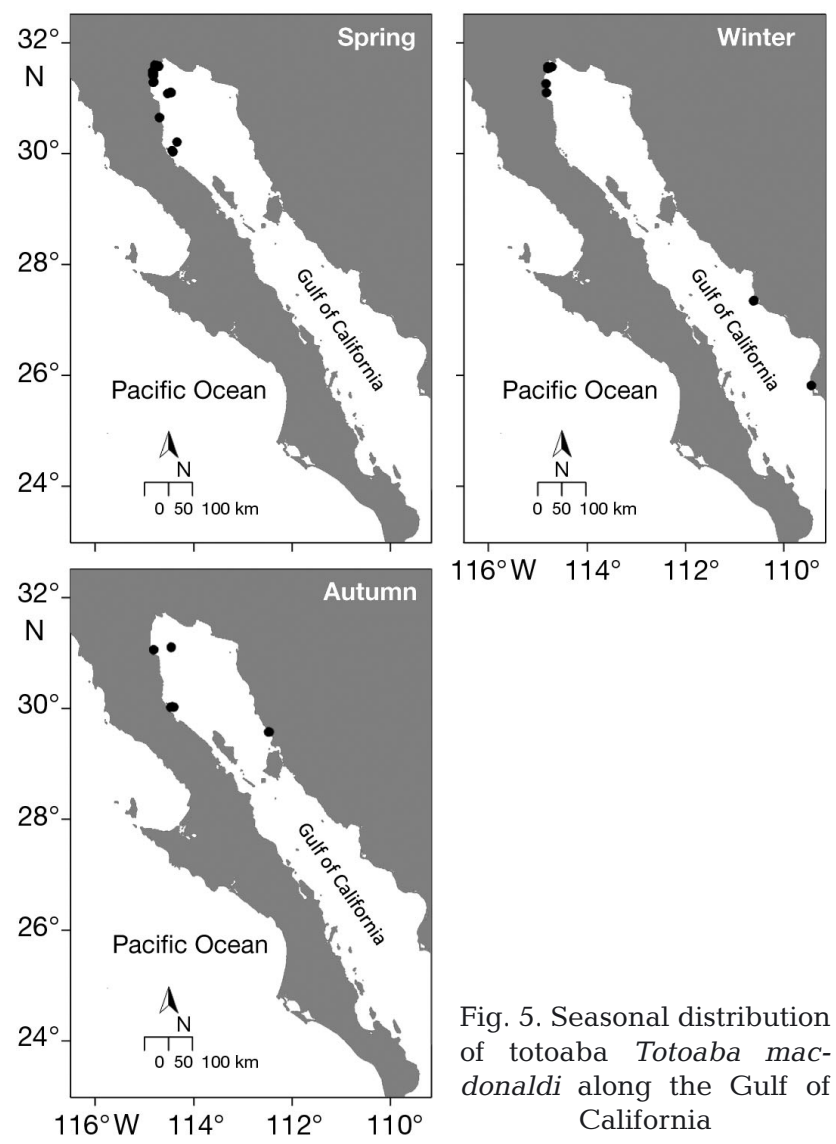

Fig. 5. Seasonal distribution of totoaba Totoaba macdonaldi along the Gulf of California

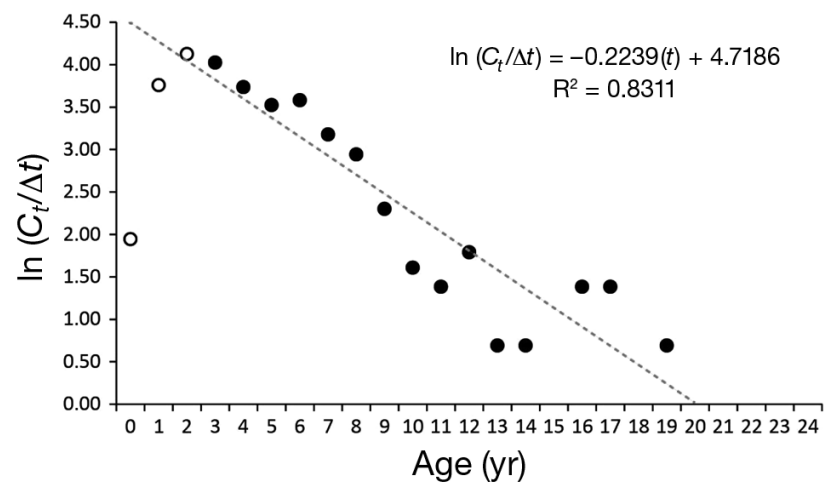

Fig. 6. Total mortality $(Z)$ estimate of totoaba Totoaba macdonaldi in the Gulf of California using the catch curve method (Sparre \& Vennema 1995). $C_{t}$ : frequency of the species at age $t$

Table 2. Estimates of the natural mortality $(M)$ of totoaba Totoaba macdonaldi using several methods from the literature. See Table 1 for the respective equations

\begin{tabular}{|lc}
\hline Method & $M \mathrm{yr}^{-1}$ \\
\hline Beverton \& Holt (1959) & 0.20 \\
Rikhter \& Efanov (1976) & 0.22 \\
Pauly (1980) & 0.19 \\
Hewit \& Hoeing (2005) & 0.14 \\
Gislason et al. (2010) & 0.19 \\
Mean \pm SD & $0.19 \pm 0.03$
\end{tabular}

contracted to the upper Gulf of California north of the islands of Tiburon and Angel de la Guarda (CITES 2010) (Fig. 1). However, the results of the present study indicate that this assumption is inaccurate. The observed distribution within the current study is similar to that prior to the population collapse (Arvizu \& Chávez 1972, Flanagan \& Hendrickson 1976, Cisneros-Mata et al. 1995). The distribution might even have increased or, at least, the survey in the present study indicated that a contraction did not occur. Indeed, migrations along the mainland coast of Mexico have been constant over the last 2 decades (F. Valenzuela-Quiñonez pers. obs.), indicating recovery or at least stability of the totoaba distribution range. Therefore, these results should be considered in future assessments of the threatened species status of totoaba.

The size structure and seasonal distribution of totoaba followed previously known patterns (Arvizu \& Chávez 1972, Cisneros-Mata et al. 1995, 1997), although the precise size composition and seasonal presence of the migrating populations have been lacking to date. In winter and spring, adults were more commonly observed in the shallow waters of 
the Colorado River delta than in other areas of the Gulf of California. The Colorado River delta is also the spawning and nursery area for totoaba (Flanagan \& Hendrickson 1976, Cisneros-Mata et al. 1995), and therefore throughout the year we observed smaller juveniles in this area. Larger juveniles were widely distributed throughout the upper and middle Gulf of California. Larger juvenile totoaba were common, and permanent, residents especially around San Luis Gonzaga and Roca Consag. At the end of autumn/ beginning of winter, juveniles of similar size were observed not only at San Luis Gonzaga, but also at the distant location of Bahía de Lobos. This observation suggests that either only part of the juvenile totoaba population migrated south or that the timing of the migration varied within the juvenile population. Further understanding of juvenile totoaba migration is still needed.

During summer, adult totoaba seek deep, cool waters (Arvizu \& Chávez 1972), whereas they were only present in the upper Gulf of California when water temperatures are low (winter and spring). This supports the presence of adults and pre-adults in the summer around the islands region (Cisneros-Mata et al. 1995), an area of high primary productivity during summer, where the water temperature is lower than that in the rest of the gulf (Soto-Mardones et al. 1999). A possible migration pattern is that totoaba migrate to the shallow waters along the coasts of the gulf when surface waters cool during early winter, but in different directions. The lack of adults in the south and the widespread distribution of large juveniles along the gulf may suggest that adults migrate northward and pre-adults migrate southward and northward along both sides of the gulf. Reverse migration to the islands (Angel de la Guarda and Tiburon) occurs at the end of spring and beginning of summer. A direct method, such as tagging, could provide more precise information on the timing and movement of individuals.

Natural mortality $(M)$ is one of the more difficult parameters to estimate in marine fish populations (Charnov et al. 2013, Kenchington 2014). Given the complexity of obtaining accurate estimates of $M$, several methods have been recommended in the literature for considering uncertainties in these estimates (Kenchington 2014). Estimates of $M$ in the present study were consistent among different methods used, ranging from 0.14 to $0.20 \mathrm{yr}^{-1}$, which is lower than previous estimates of $M$ for totoaba ( $M=0.268$; Cisneros-Mata et al. 1995). Observed differences among estimates within the present study might reflect the different life history parameters used in the calcula- tion of $M$ (Table 1). The total mortality estimate $(Z=$ 0.22 ) for totoaba in our study was below the range reported for totoaba prior to $(Z=0.41$; Berdegué 1955) and after the fishing ban $(Z=0.41-0.73$; Molina-Valdez et al. 1988, Cisneros-Mata et al. 1995, Pedrín-Osuna et al. 2001). Differences in estimates of $Z$ arise from differences in methods employed, modal size groups caught, and sampling sizes among studies. There was a small difference between $Z$ and $M$ estimated in the present study $\left(Z-M_{\text {average }}=0.03\right)$, likely reflecting the mortality from illegal fishing, which was almost inexistent before the year 2013. Illegal fishing could explain the relative approximation of $Z \approx M$, but this effect remains unclear. The magnitude of poaching significantly increased at the beginning of 2013. Thus, an increase in $Z$ for totoaba is expected in the future. Estimates of $M$ and $Z$ can be used as input in demographic or stock assessment models to assess the population status of totoaba, using the uncertainty of these parameters ( $M$ and $Z$ ).

Gear selectivity is the main factor impacting the size structure in exploited marine fishes, which is, in turn, related to the resilience of the population (Brunel \& Piet 2013). The catch composition also depends on gear selectivity, which has been proposed as an indicator of sustainable catches (Froese 2004, Cope \& Punt 2009). How totoaba size structure was affected by bycatch of the sport fishery (hooks) and illegal fishing by poachers (gillnet) was previously unknown. In the current study, hooks caught almost exclusively juveniles, while gillnets caught mainly adults but also a large number of juveniles. These findings pose a potential threat for totoaba since the size at first maturity is $1300 \mathrm{~mm}$ in total length (De-Anda-Montañez et al. 2013). Thus, neither gear meets the criteria for sustainable catches that avoid exploitation of juveniles and instead focus on mature adults (Froese 2004, Cope \& Punt 2009). In the hypothetical case of reopening the totoaba fishery, legalizing either of these 2 methods would involve risks to the totoaba population. However, this needs to be examined, in a formal evaluation, by conducting a selectivity experiment (Millar \& Fryer 1999, Hovgård \& Lassen 2000) to explore the potential effects on the totoaba population.

\section{Conservation implications}

Totoaba have been listed as Critically Endangered since 1976 (CITES 2010). However, the criteria to assess the status of totoaba were not consolidated until 2000 (IUCN 2001). Thus, totoaba were listed as 
Critically Endangered before the criteria to determine the threat level were well established. Totoaba are still considered Critically Endangered, and this status is supported by information from the middle of the 20th century (Valenzuela-Quiñonez et al. 2011). The lack of a monitoring program after the fishing ban in 1975 resulted in a lack of usable records and updated information, making it difficult to assess the current population status. Evidence from the present study and other studies (De-Anda-Montañez et al. 2013, Valenzuela-Quiñonez et al. 2014) indicates that totoaba maintain their known life history almost $40 \mathrm{yr}$ after population collapse. The current distribution area of totoaba is in the range of its known historical distribution in the Gulf of California (Flanagan \& Hendrickson 1976, Cisneros-Mata et al. 1995). The size structure was not truncated, as expected in overexploited species. The size structure and seasonal distributions were consistent with the known migration pattern of totoaba (Cisneros-Mata et al. 1995). Totoaba still spawns in the Colorado River delta under anti-estuarine conditions (De-Anda-Montañez et al. 2013), suggesting that the species does not exhibit estuarine-dependent behavior as previously established (Flanagan \& Hendrickson 1976, Cisneros-Mata et al. 1995, Valdez-Muñoz et al. 2010, Bobadilla et al. 2011, Valenzuela-Quiñonez et al. 2011). The genetic diversity of totoaba is sufficient for long-term conservation and is similar to several healthy marine fish (Valenzuela-Quiñonez et al. 2014), suggesting that the population collapse in the 20th century did not affect the overall general life history of totoaba. Hence, the threatened status of totoaba should be re-evaluated using this new information. Although the full recovery status cannot be established due to lack of baseline information prior to the collapse (Abbitt \& Scott 2001, Lotze et al. 2011, Redford et al. 2011), indirect evidence showed positive signs of recovery.

The current main threat to totoaba is illegal fishing, which is encouraged by the high price of the totoaba gas bladder (buche), with a value of up to US\$5000 $\mathrm{kg}^{-1}$ on the local black market (2013 season) (F. ValenzuelaQuiñonez pers. obs. fishermen interview 2013). Gas bladders are exported to the USA and Asia, where the prices are even higher. This black market exploitation has resulted in increased illegal fishing of totoaba since January 2013, aided by a lack of effective surveillance. Poachers use gillnets prohibited for fishing activities in the upper Gulf of California and fish in areas where all fishing activities are prohibited. Illegal activity is especially common during the spawning season, when totoaba are most vulnerable and before the adults are able to spawn. This practice could lead to the loss of self-replacement and prevent potential recovery.

Totoaba conservation is complex. The results of the present study showed that totoaba maintain their life history and show signs of recovery. However, illegal fishing has been increasing, thereby preventing positive recovery of the totoaba population. Managers might reconsider changing the threat status of totoaba, but the vulnerability of these long-lived fish should also be considered. Nevertheless, a full stock or a demographic assessment is necessary to establish whether the population has fully recovered, and whether this population can support fishing mortality should be determined. Notably, any decision to use totoaba as a fishery resource is risky if taken before the population status has been fully evaluated.

Acknowledgments. This work was conducted in memory of Rafael Campoy Fávela, who encouraged the study of this symbolic species of this natural reserve (Biosphere Reserve of the Upper Gulf of California and the Colorado River delta) and dedicated his life's work to this cause, and Tony Reyes, who requested the Mexican government to study totoaba for determining its use as a resource. The authors thank Lucia Campos Dávila, Norma Monroy Olguín, Juan José Ramírez Rosas, José Isboset Saldaña, Marcela Vélez Alavez, Laura Rivera Rodríguez, and the Fishermen Federation of San Felipe and Golfo de Santa Clara for assistance with fieldwork. Ira Fogel of CIBNOR provided editorial services. Funding was provided by the Comisión para el Conocimiento y Uso de la Biodiversidad (CONABIO Grant FB1508/ HK050/10), particularly to Luis Fueyo Macdonald, and the Mexican Consejo Nacional de Ciencia y Tecnología (CONACYT Grant CB-2011-01; 165376). The authors also thank the Secretaría de Medio Ambiente y Recursos Naturales through the Dirección General de Vida Silvestre for issuing permits (SGPA/DGVS/02913/10, SGPA/DGVS/05508/11, and SGPA/DGVS/00039/13) to conduct fieldwork, particularly to Roberto Aviña Carlin, Benjamín González Brizuela, and Fernando Sánchez Camacho. F.V.Q. was the recipient of a student fellowship (CONACYT 46305).

\section{LITERATURE CITED}

Abbitt RJF, Scott JM (2001) Examining differences between recovered and declining endangered species. Conserv Biol 15:1274-1284

Aguirre-Villaseñor H, Morales-Bojórquez E, Morán-Angulo RE, Madrid-Vera J, Valdez-Pineda MC (2006) Indicadores biológicos de la pesquería de sierra (Scomberomorus sierra) al sur del Golfo de California, México. Cienc Mar 32:471-484

Andersen KH, Beyer JE (2015) Size structure, not metabolic scaling rules, determines fisheries reference points. Fish Fish 16:1-22

Arvizu J, Chávez H (1972) Sinopsis sobre la biología de la totoaba Cynoscion macdonaldi Gilbert, 1890. FAO Fish Biol Synop 108:1-26 
Barrera-Guevara JC (1990) The conservation of Totoaba macdonaldi (Gilbert), (Pisces: Sciaenidae), in the Gulf of California, Mexico. J Fish Biol 37:201-202

Berdegué AJ (1955) La pesqueria de la totoaba (Cynoscion macdonaldi) en San Felipe, Baja California. Rev Soc Mex Hist Nat 16:45-78

Beverton RJH, Holt SJ (1959) A review of the lifespans and mortality rates of fish in nature, and their relation to growth and other physiological characteristics. In: Wolstenholme GEW, O'Connor M (eds) Ciba Foundation Symposium - the lifespan of animals (Colloquia on ageing), Vol 5. Churchill, London, p 142-180

> Bobadilla M, Alvarez-Borrego S, Avila-Foucat S, LaraValencia F, Espejel I (2011) Evolution of environmental policy instruments implemented for the protection of totoaba and the vaquita porpoise in the upper Gulf of California. Environ Sci Pol 14:998-1007

> Brunel T, Piet GJ (2013) Is age structure a relevant criterion for the health of fish stocks? ICES J Mar Sci 70:270-283

> Charnov EL, Gislason H, Pope JG (2013) Evolutionary assembly rules for fish life histories. Fish Fish 14:213-224

> Cisneros-Mata MA, Montemayor-López G, RománRodríguez MJ (1995) Life history and conservation of Totoaba macdonaldi. Conserv Biol 9:806-814

Cisneros-Mata MA, Botsford LW, Quinn JF (1997) Projecting viability of Totoaba macdonaldi, a population with unknown age-dependent variability. Ecol Appl 7:968-980

CITES (2010) Review of cites appendixes based on resolution conf. 9.24 (rev.) Totoaba macdonaldi (Mexican seabass) in: www.cites.org/sites/default/files/common/ com/ac/17/E17i-06.pdf (accessed on 8 June 2010)

Cope JM, Punt AE (2009) Length-based reference points for data-limited situations: applications and restrictions. Mar Coast Fish Dynam Manag Ecosys Sci 1:169-186

Costello C, Ovando D, Hilborn R, Gaines SD, Deschenes O, Lester SE (2012) Status and solutions for the world's unassessed fisheries. Science 338:517-520

De-Anda-Montañez J, García de León F, Zenteno Savín T, Balart EF, and others (2013) Estado de salud y estatus de conservación de la(s) poblacion(es) de totoaba (Totoaba macdonaldi) en el Golfo de California: una especie en peligro de extinción. Comisión Nacional para el Conocimiento y Uso de la Biodiversidad, La Paz

Dulvy NK, Sadovy Y, Reynolds JD (2003) Extinction vulnerability in marine populations. Fish Fish 4:25-64

- Eikeset AM, Richter A, Dunlop ES, Dieckmann U, Stenseth NC (2013) Economic repercussions of fisheries-induced evolution. Proc Natl Acad Sci USA 110:12259-12264

Enberg K, Jørgensen C, Dunlop ES, Heino M, Dieckmann U (2009) Implications of fisheries-induced evolution for stock rebuilding and recovery. Evol Appl 2:394-414

Fisher JAD, Frank KT, Leggett WC (2010) Breaking Bergmann's rule: truncation of Northwest Atlantic marine fish body sizes. Ecology 91:2499-2505

Flanagan CA, Hendrickson R (1976) Observations on the commercial fishery and reproductive biology of the totoaba Cynoscion macdonaldi in the northern Gulf of California. Fish Bull 74:531-544

Froese R (2004) Keep it simple: three indicators to deal with overfishing. Fish Fish 5:86-91

- Gislason H, Daan N, Rice JC, Pope JG (2010) Size, growth, temperature and the natural mortality of marine fish. Fish Fish 11:149-158

Haddon M (2001) Modelling and quantitative methods in fisheries. CRC Press, New York, NY
Heino M, Baulier L, Boukal DS, Ernande B, and others (2013) Can fisheries-induced evolution shift reference points for fisheries management? ICES J Mar Sci 70: 707-721

Hewitt DA, Hoenig JM (2005) Comparison of two approaches for estimating natural mortality based on longevity. Fish Bull 103:433-437

Hilborn R, Walters CJ (1992) Quantitative fisheries stock assessment: choice, dynamics and uncertainty, Springer, New York, NY

Hoarau G, Boon E, Jongma DN, Ferber S, and others (2005) Low effective population size and evidence for inbreeding in an overexploited flatfish, plaice (Pleuronectes platessa L.). Proc R Soc B Biol Sci 272:497-503 doi:10.1098/ rspb.2004.2963

Hovgård H, Lassen H (2000) Manual on estimation of selectivity for gillnet and longline gears in abundance surveys. FAO Fish Tech Pap 397:1-84

Hutchings JA (2000) Collapse and recovery of marine fishes. Nature 406:882-885

Hutchings JA, Reynolds JD (2004) Marine fish population collapses: consequences for recovery and extinction risk. Bioscience 54:297-309

IUCN (International Union for Conservation of Nature) (2001) Categorías y criterios de la lista roja de la UICN. Versión 3.1, 1st edn, IUCN, Gland

IUCN (2013) IUCN Red List of Threatened Species. Version 2013.1. IUCN, Gland (accessed on 2 May 2013)

Kenchington TJ (2014) Natural mortality estimators for information-limited fisheries. Fish Fish 15:533-562

> Lercari D, Chávez EA (2007) Possible causes related to historic stock depletion of the totoaba, Totoaba macdonaldi (Perciformes: Sciaenidae), endemic to the Gulf of California. Fish Res 86:136-142

Lotze HK, Coll M, Magera AM, Ward-Paige C, Airoldi L (2011) Recovery of marine animal populations and ecosystems. Trends Ecol Evol 26:595-605

Márquez-Farías JF, Rosales-Juárez FJ (2013) Intrinsic rebound potential of the endangered (Totoaba macdonaldi) population, endemic to the Gulf of California, México. Fish Res 147:150-153

Millar R, Fryer R (1999) Estimating the size-selection curves of towed gears, traps, nets and hooks. Rev Fish Biol Fish 9:89-116

Molina-Valdez D, Cisneros-Mata MA, Urias-Sotomayor R, Cervantes-Vaca C, Marquez-Tiburcio MA (1988) Prospección y evaluación de la totoaba (Totoaba macdonaldi) en el Golfo de California. Centro Regional de Investigaciones Pesqueras, Instituto Nacional de la Pesca, Guaymas, Sonora, Informe Final CONACYT

Neter J, Kutner MH, Nachtsheim CJ, Wasserman W (1996) Applied linear statistical models, 4th edn. McGraw-Hill, New York, NY

Pauly D (1980) On the interrelationships between natural mortality, growth parameters, and mean environmental temperature in 175 fish stocks. J Cons Int Explor Mer 39: 175-192

Pedrín-Osuna OA, Córdova-Murueta JH, Delgado-Marchena M (2001) Crecimiento y mortalidad de la totoaba, Totoaba macdonaldi, del alto Golfo de California. Cienc Pesq 14:131-138

R Development Core Team (2011) R: a language and environment for statistical computing. R Foundation for Statistical Computing, Vienna

Redford KH, Amato G, Baillie J, Beldomenico P, and others 
(2011) What does it mean to successfully conserve a (vertebrate) species? Bioscience 61:39-48

Reynolds JD, Dulvy NK, Goodwin NB, Hutchings JA (2005) Biology of extinction risk in marine fishes. Proc R Soc B Biol Sci 272:2337-2344

Rikhter VA, Efanov VM (1976) On one of the approaches to estimation of natural mortality of fish population. ICNAF, Res Doc 76/VI/8:1-12

Román-Rodríguez M, Hammann GM (1997) Age and growth of totoaba, Totoaba macdonaldi (Sciaenidae), in the upper Gulf of California. Fish Bull 95:620-628

Rosales-Juárez F, Ramírez-González E (1987) Estado actual sobre el conocimiento de la totoaba: (Cynoscion macdonaldi, Gilbert 1890). Secretaría de Pesca, México D.F.

Schnute JT, Boers NM, Haigh R, Station PB (2004) PBS mapping 2: user's guide. Can Tech Rep Fish Aquat Sci 2549: $1-126$

Soto-Mardones L, Marinone SG, Parés-Sierra A (1999) Time and spatial variability of sea surface temperature in the Gulf of California. Cienc Mar 25:1-30
Sparre P, Vennema SC (1995) Introducción a la evaluación de recursos pesqueros tropicales, Parte 1. FAO Fish Tech Pap 306.1

Valdez-Muñoz C, Aragón-Noriega EA, Ortega-Rubio A, Salinas-Zavala CA, Arreola-Lizárraga JA, HernándezVázquez S, Beltrán Morales LF (2010) Distribución y abundancia de juveniles de totoaba Totoaba macdonaldi y la salinidad del hábitat de crianza. Interciencia 35: 136-139

Valenzuela-Quiñonez F, García-de-León F, De-Anda-Montañez J, Balart EF (2011) La totoaba del golfo de California ¿̇una especie en peligro de extinción? Interciencia 36: 664-671

Valenzuela-Quiñonez F, Garza JC, De-Anda-Montañez JA, García-de-León FJ (2014) Inferring past demographic changes in a Critically Endangered marine fish after fishery collapse. ICES J Mar Sci 71:1619-1628

Vasilakopoulos P, O'Neill FG, Marshall CT (2011) Misspent youth: Does catching immature fish affect fisheries sustainability? ICES J Mar Sci 68:1525-1534

\section{Appendix}

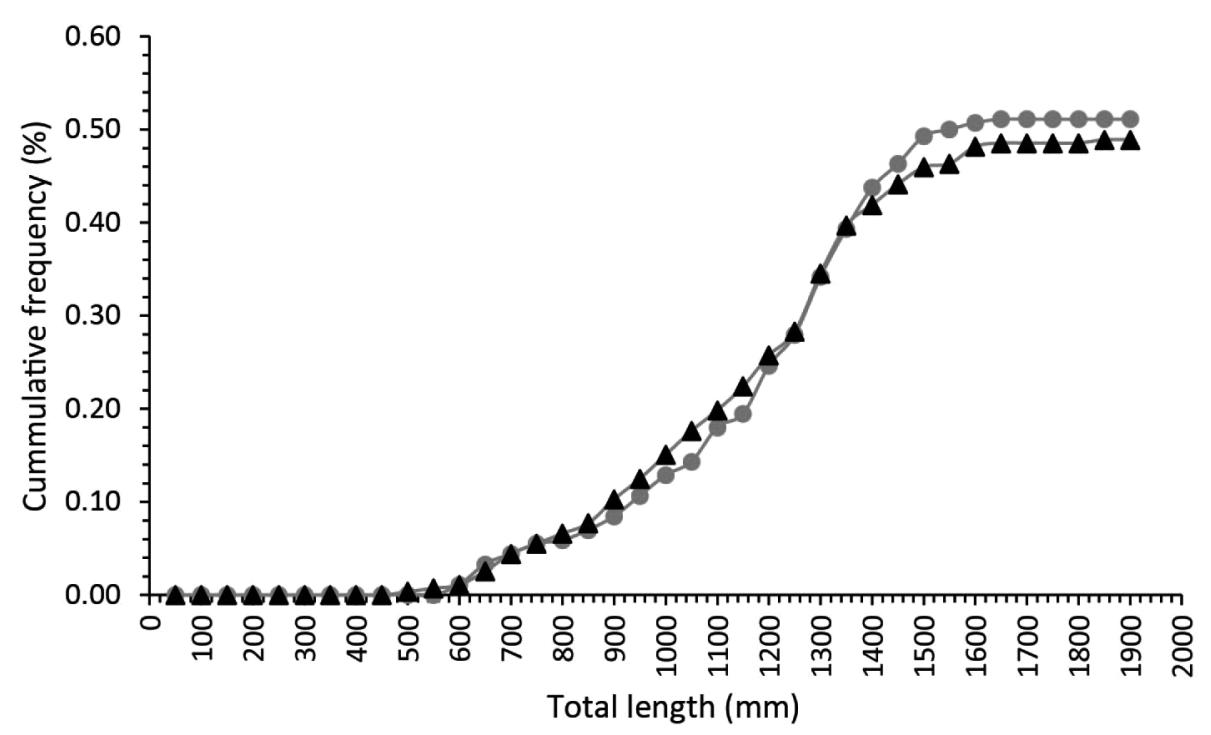

Fig. A1. Cumulative frequency at length for males (triangles) and females (circles) to discriminate hypothetical growth differences between sexes

Editorial responsibility: Eric Gilman,

Honululu, Hawaii, USA
Submitted: April 24, 2015; Accepted: August 22, 2015 Proofs received from author(s): October 27, 2015 